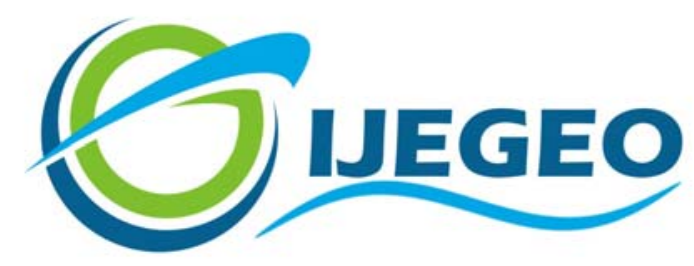

International Journal of Environment and Geoinformatics (IJEGEO) is an international, multidisciplinary, peer reviewed and open access journal.

\title{
Underwater Noise Pollution at the Strait of Istanbul (Bosphorus)
}

\section{Cem Gazioğlu and Volkan Okutan}

\section{Editors}

Prof. Dr. Cem Gazioğlu, Prof. Dr. Dursun Zafer Şeker, Prof. Dr. Ayşegül Tanık, Assoc. Prof. Dr. Şinasi Kaya

\section{Scientific Committee}

Assoc. Prof. Dr. Hasan Abdullah (BL), Assist. Prof. Dr. Alias Abdulrahman (MAL), Assist. Prof. Dr. Abdullah Aksu, (TR); Assist. Prof. Dr. Sinan S. Arkın (TR), Prof. Dr. Hasan Atar (TR), Prof. Dr. Lale Balas (TR), Prof. Dr. Levent Bat (TR), Assoc. Prof. Dr. Füsun Balık Şanlı (TR), Prof. Dr. Nuray Balkıs Çağlar (TR), Prof. Dr. Bülent Bayram (TR), Prof. Dr. Şükrü Turan Beşiktepe (TR), Prof. Dr. Z. Selmin Burak (TR), Assoc. Prof. Dr. Gürcan Büyüksalih (TR), Dr. Jadunandan Dash (UK), Assist. Prof. Dr. Volkan Demir (TR), Assoc. Prof. Dr. Hande Demirel (TR), Assoc. Prof. Dr. Nazlı Demirel (TR), Dr. Arta Dilo (NL), Prof. Dr. A. Evren Erginal (TR), Assoc. Prof. Dr. Murat Gündüz (TR), Assoc. Prof. Dr. Kensuke Kawamura (JAPAN), Prof. Dr. Fatmagül Kılıç (TR), Prof. Dr. Ufuk Kocabaş (TR), Prof. Dr. Yusuf Kurucu (TR), Prof. Dr. Hakan Kutoğlu (TR), Prof. Dr. Nebiye Musaoğlu (TR), Prof. Dr. Erhan Mutlu (TR), Assist. Prof. Dr. Hakan Öniz (TR), Assoc. Prof. Dr. Hasan Özdemir (TR), Assoc. Prof. Dr. Barış Salihoğlu (TR), Prof. Dr. Elif Sertel (TR), Prof. Dr. Kadir Seyhan (TR), Prof. Dr. Murat Sezgin (TR), Prof. Dr. Nüket Sivri (TR), Assoc. Prof. Dr. Uğur Şanlı (TR), Assoc. Prof. Dr. Seyfettin Taş (TR), Assoc. Prof. Dr. İ. Noyan Yılmaz (TR), Assist. Prof. Dr. Baki Yokeş (TR), Assist. Prof. Dr. Sibel Zeki (TR), Dr. Hakan Kaya (TR). 


\title{
Underwater Noise Pollution at the Strait of Istanbul (Bosphorus)
}

\author{
Cem Gazioğlu* and Volkan Okutan \\ Istanbul University, Institute of Marine Sciences and Management, Department of Marine Environment, 34134 Vefa Fatih \\ Istanbul TR
}

* Corresponding author. Tel: ++90 2124400000 \# 26004

Received: 03 June 2016

E-mail: cemga@istanbul.edu.tr

\begin{abstract}
Underwater noise pollution (UNP) has become a major concern in marine habitats, which is intense anthropogenic noise in the marine (aquatic) environment. It is caused by ship traffic, oceanographic experiments, and use of explosives in geophysical research, underwater construction, active sonars and seismic survey techniques. Oceans are much nosier than 1960s. Narrow and shallow channel noisy aquatic environments where noise levels reach the highest value is not surprising. The Strait of Istanbul (SoI; Bosphorus) is one of the most important maritime passages (app. $50000 \mathrm{vessel} / \mathrm{year}$ or $140 \mathrm{vessel} /$ day) which is situated between the Black Sea and the Aegean Sea are also biologically extremely important gateway not only it provides access to a channel. Many of the varieties of fish migration hunting value are realized through the TSS. Local maritime traffic is another important acoustic sources which are more than 3000 elements (Kesgin and Vardar, 2001) of everyday local traffic in SoI, which are causing noise in the 2 and $10 \mathrm{kHz}$ range. Large vessels create signals both in bands below $1 \mathrm{kHz}$ (main engine, electrical instruments) cavitation noise creates higher frequency bands. Almost all elements of marine traffic in SoI located therefore encountered UND in all bands.
\end{abstract}

Keywords: Strait of Istanbul, Underwater noise pollution, Ocean ambient noise, acoustic ecology.

\section{Introduction}

Since the industrial revolution, the soundscape of the marine environment (ME) has responded to the changes in anthropogenic impacts. A soundscape is a combination of sounds that characterize and describe an ocean environment, as known as acoustic ecologyenvironment (AEE) which has doubled in each of the past four decades (McDonald et al., 2006). The disruption of the natural AEE which is categorized by spatial and time dependent variability will be caused by the anthropogenic UNP (Etter, 2012).

Environmental noise in the ocean is an important aspect of marine habitats and is composed of natural and artificial sounds (Hildebrand, 2009). Since 1960s, the increase of human activities along coastlines worldwide and in the sea has caused an commensurate increase in the Ocean Ambient Noise (OAN), especially in the low frequency range $(<500$
$\mathrm{Hz})$ where noise produced by many anthropogenic activities is concentrated with physiological, behavioral, and population effects on marine animals (Slabbekoorn et al., 2010; Sebastianutto et al., 2016). However, over the recent decades UNP has come to the attention of scientists as a rising problem around the world's oceans (McDonald et al., 2006).

Sound is an extremely proficient way to propagate energy through the ocean for far distance and some marine life forms exploit this property for communicate their own kind and most of them use for navigate and migration. Ocean Ambient Noise is one of the important features of marine life forms for navigation (Richardson et al. 1995, Halpern et al. 2008). Fish utilize sound especially for navigation, surviving, procreation and communication (Ketten and Wartzok 1999; Bass and McKibben 2003, Simpson et al. 2005; Hildebrand, 2009; Gazioğlu et al., 2015). Accordingly, worldwide OAN has increased correspondingly due to 
amplified anthropogenic activities, which describe as UNP (Kastelein et al., 2008). Sound is known as significant navigational indication for all organisms in aquatic environs especially marine mammals. In general, since the amount of anthropogenic noise is higher in the low frequency range, fish were potentially more damagingly impacted by the noise conditions than marine mammals in the same area (Sebastianutto et al., 2016). Animals are capable of amazing feats of migration and navigation. Directed long-distance migrations Animals are capable of amazing feats of migration and navigation. Directed long-

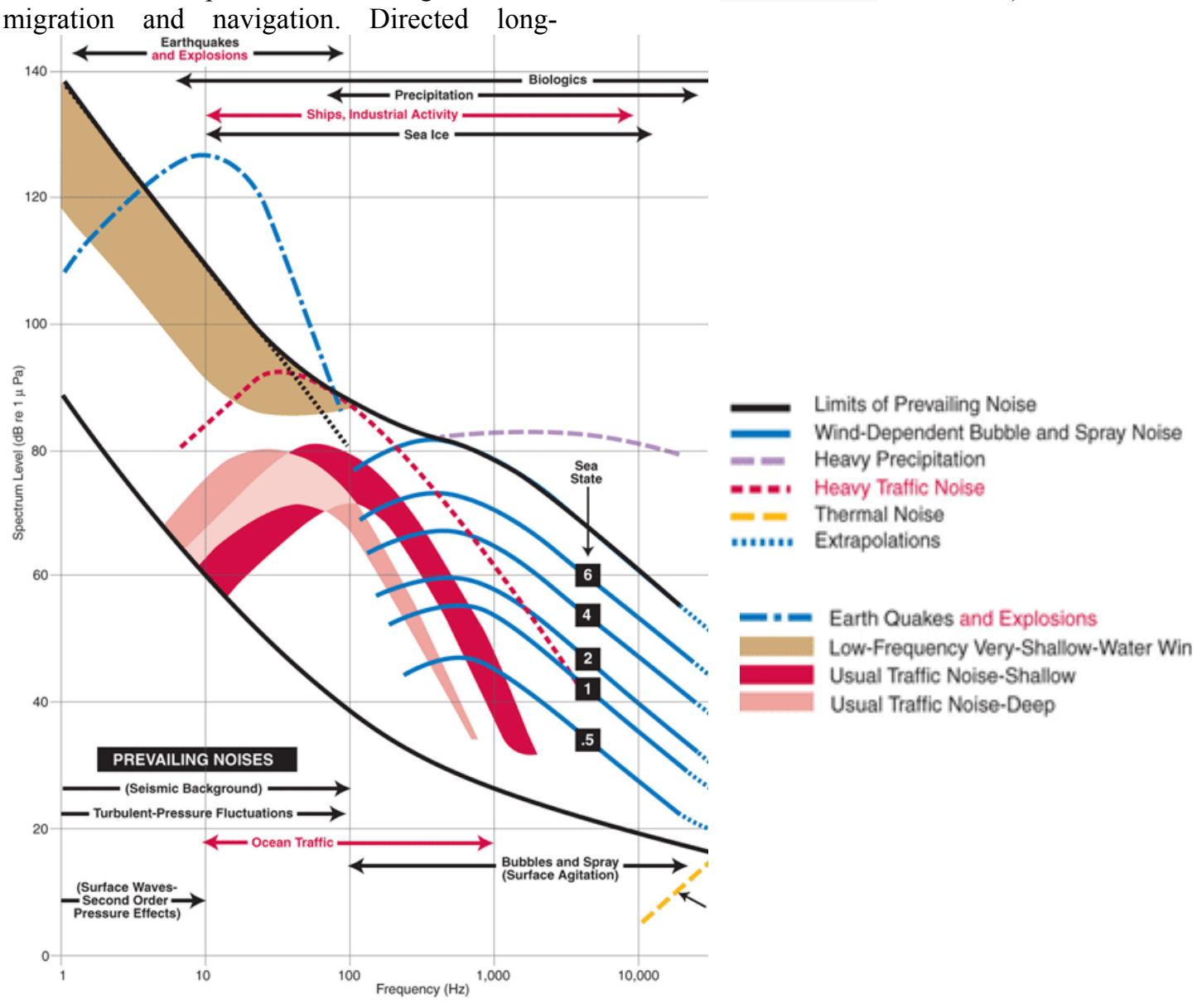

a.

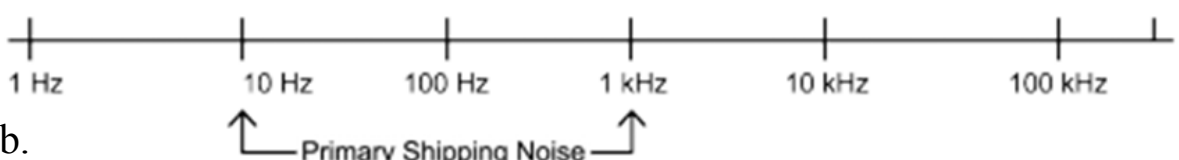

Fig. 1 a. OAN Spectra. Adapted from Wenz (1962) b. Marine Traffic Spectra.

27 


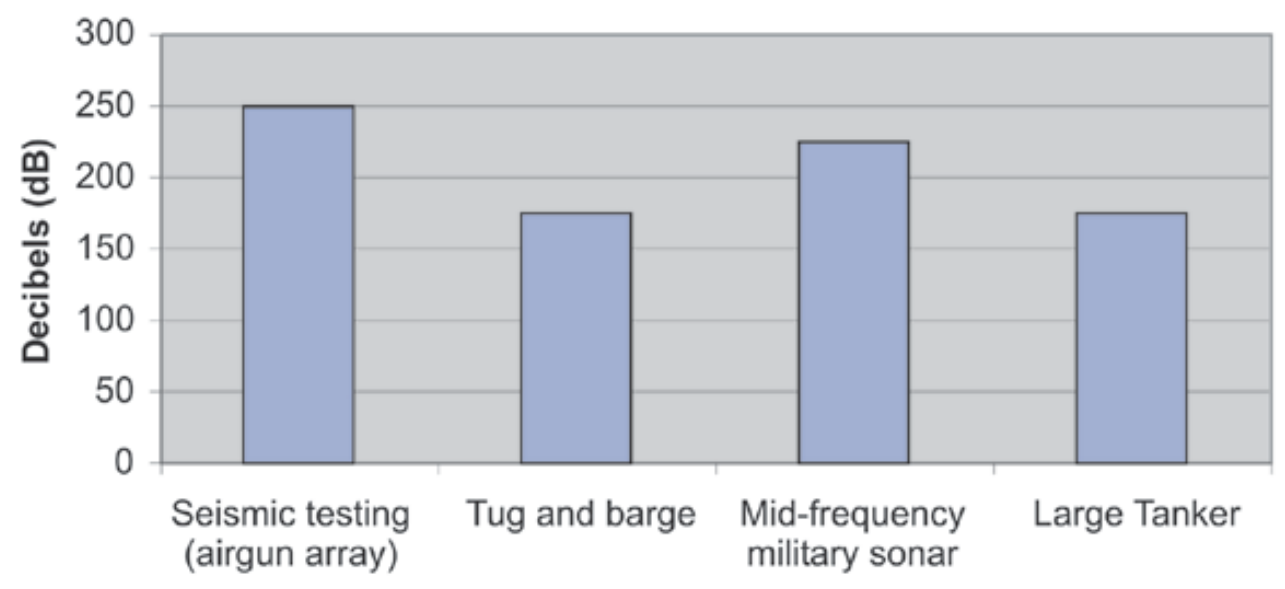

Human-made ocean sounds

Fig 2. Example sources for acoustic ecology-environment.

Ship noise (SN) is generated primarily from propeller cavitation, propeller singing and propulsion or other reciprocating machinery Fig. 1a-b (Richardson et al., 1995; Wales and Heitmeyer, 2002; Hildebrand, 2009, Veirs et al., 2016). Ship noise has become the main sound source in coastal areas and may have effects on the AEE (Richardson et al., 1995; Tyack, 2008; Castellote et al., 2012). Higher frequency signals, between 2 and $10 \mathrm{kHz}$ created by small ships. Large vessels create signals both in bands below $1 \mathrm{kHz}$ due to main engine and electrical instruments and in higher frequency bands due to cavitation noise (Wenz, 1962; Arveson and Vendittis, 2000; Aguilar Soto et al., 2006; Bittencourt, et al., 2014). Ship noise of close range and through strait is differentiated from traffic noise at open seas. It may be identified by short term variations in the OAN characteristics, such as the temporary form of narrow band components and a comparatively rapid rise and fall in noise level. Ship noise causes short-term variations in the OAN characterized by the temporary appearance of narrow-band. Marine traffic is pervasive throughout the ME, particularly at low frequencies and is therefore a key concern regarding the effects of chronic noise exposure on marine creatures Fig.2 and Table 1. (Merchant et al., 2012a). Ship noise characteristics base is broad so that individual differences blend into an average source characteristic (Wenz, 1962).

Table 1. Ocean Sound intensity in water dB.

\begin{tabular}{|l|l|}
\hline Ocean Sound & $\begin{array}{l}\text { Sound intensity in water } \\
\text { dB (Rounded off) }\end{array}$ \\
\hline Seismic testing (airgun array) & $<200$ \\
\hline Tug and barge (18 km/hour) & $170 \pm 5$ \\
\hline Mid-frequency military sonar & $<235$ \\
\hline Tanker (<80 000 DWT) & $<185$ \\
\hline Sea floor volcanic eruption & $<255$ \\
\hline $\begin{array}{l}\text { Lightning strike on the ocean's } \\
\text { surface }\end{array}$ & $<260$ \\
\hline
\end{tabular}


Shipping plays an unquestionably important role in the nowadays world's economy and commercial ship traffic has tripled in the last 75 years, resulting in a 3-5 $\mathrm{dB}$ increase per decade of noise in the oceans. A large modern tanker

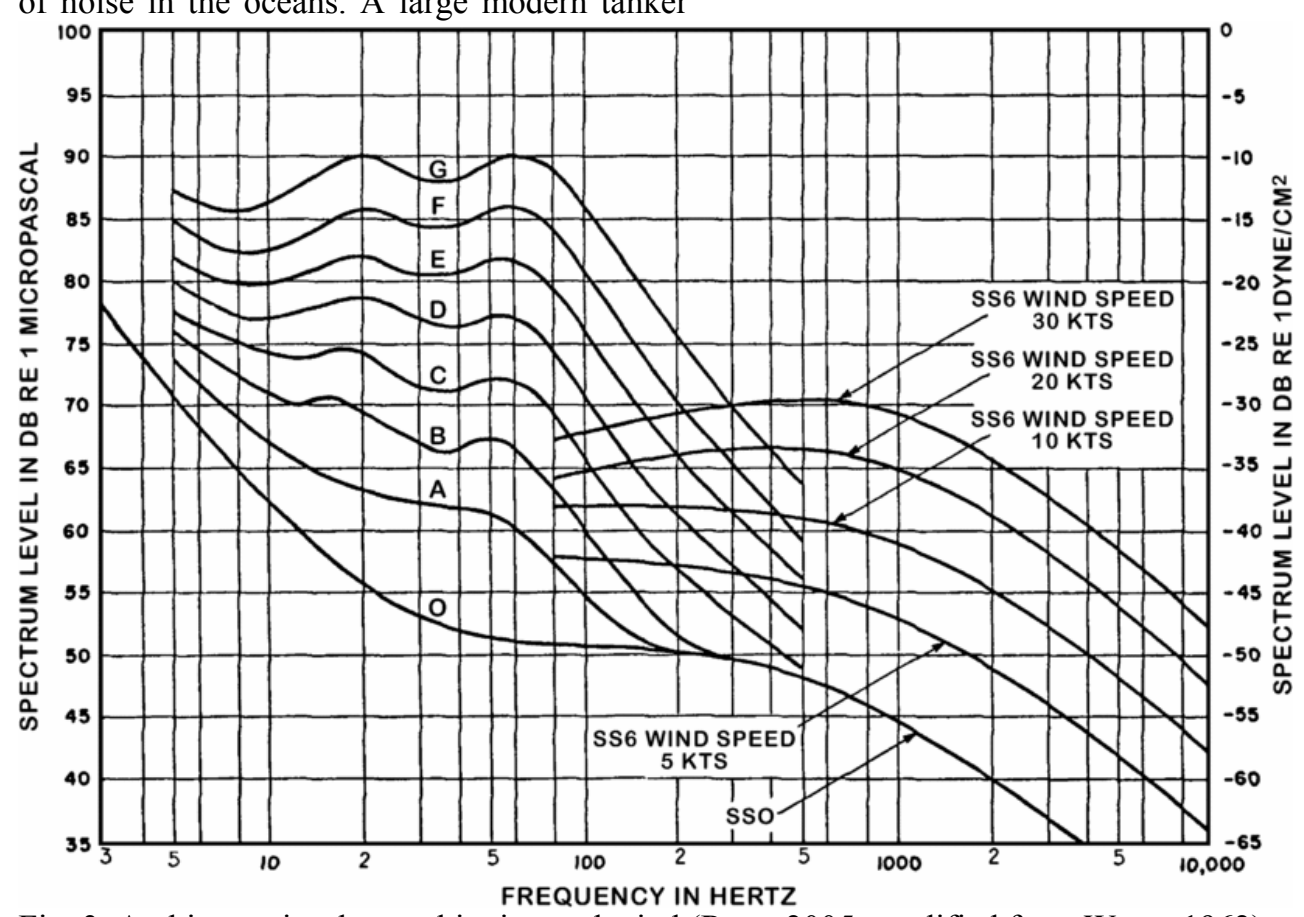

Fig. 3. Ambient noise due to shipping and wind (Ross, 2005: modified from Wenz, 1962)
The areas between the lines in figure 3 until that used to be in the $\mathrm{B}$ to $\mathrm{C}$ region (typical of the Pacific Ocean 1960-1980) have moved up into the D to E region; and areas that used to be in the $\mathrm{D}$ to $\mathrm{E}$ region at the time these curves were developed have moved up into the $F$ to $G$ region. In addition, two more curves have been required going up to 95 and $100 \mathrm{~dB}$ to Atlantic and moreover for the Mediterranean in nowadays (Fig. 3 modified from Wenz, 1962).

Low and mid-frequency impulsive sound $(10 \mathrm{~Hz}-10 \mathrm{kHz})$ where the focus is $\mathrm{SN}$. (Dekeling et al., 2013). The average yearly sound levels in third-octave bands with center frequencies at $63 \mathrm{~Hz}$ and $125 \mathrm{~Hz}$ have been set as the indicator for the second attribute. Thirdoctave bands are described by the sum of the sound power occurring within defined encompass data acquired for the eastern reaches more than $190 \mathrm{~dB}$ in normal condition cruise. Some research suggested that $\mathrm{SN}$ has increased at a rate of about $1 / 2 \mathrm{~dB}$ per year (Ross, 2005) and it will be carry on. frequency bands, one third of an octave wide. Propeller cavitation noise, from vessels underway, is known to peak in the frequency range 50-150 Hz (Ross, 1976). These two third-octave bands are therefore considered to capture the anthropogenic contribution from shipping while also minimizing the input from natural sources (Tasker et al., 2010; Van der Graaf et al., 2012).

Measurements of low-frequency third-octave levels have taken place at many locations around the world and range from short(minutes) to long-term $(<10$ years) (Garrett et al., 2016):

- continental slope offshore California, within $10-500 \mathrm{~Hz}$ for 7 years (Andrew et al., 2002), 
- offshore British Columbia at $<1.6$ $\mathrm{kHz}$ for 4 months (Merchant et al., 2012b),

- shallow archipelago in Croatia with touristic boating activity for 5 month-2 years (Rako et al., 2013),

- deep waters: channel in the Atlantic, Indian, and Pacific Oceans using hydroacoustic explosion-monitoring stations at $<125 \mathrm{~Hz}$ for 42 months (van der Schaar et al., 2014),

- the North Atlantic and the North Pacific from the 1950s through the 1970s, Ross (2005) showed an average noise at $50 \mathrm{~Hz}$ (mainly due to shipping) was increasing 5.5 $\mathrm{dB} /$ decade,

- Salish Sea: inland waters of Washington State and British Columbia for 28 moths (Veirs et al., 2016).

Surface wave motion and turbulence as hydrostatic OAN source of the effects of low frequency $(<100 \mathrm{~Hz})$ is evident which decreases with increasing depth where the recipient resides. Wind turbulence induced depends on sea conditions, spray, bubbles, and effects such as foam, usually dominant at frequencies above $500 \mathrm{~Hz}$ (Urick 1983). However, this effect creates waves breakage, occur in a significant way in the deep seas and high wind speeds. The measurement of the work done and the conditions into account, OAN to a large extent dominated by the noise source is understood that the sea traffic. Across the spectrum of $\mathrm{SN}$ and/or maritime traffic noise of $10-1000 \mathrm{~Hz}$ frequency range is given by recent references (Veirs, 2016).

Measurements at the Turkish seas have shown that the OAN in the SoM is about $95 \mathrm{~dB}$ and 4 $\mathrm{dB}$ (decibel) noisier than surrounding seas (Mutlu 2005). According to latest acoustic investigations show that data showed that the noisiest area is located between Beşiktaş and Üsküdar in the southern part of the SoI, where the noise levels are $120 \mathrm{~dB}$ at low and mid frequencies (Tombul and Alpar, 2016). This is due to heavy local shipping, turbulence and the noise from the nearby suspended bridge (Ülüğ, 2009).

\section{Method \\ Location (Study Area)}

The TSS is a series of internationally significant waterwards in northwest Turkey that connect the Aegean and Mediterranean seas to the Black Sea. They consist of the strait of Çanakkle (SoÇ: Dardanelles), the Sea of Marmara (SoM) and the Strait of Istanbul (SoI: Bosphorus). The TSS is one of the most crowded sea lanes in the world used for international navigation which in the straits is highly congested by merchant ships: approximately $50 \quad 000$ vessel/year or 150 vessel/day (Terzi and Gazioğlu, 2016).

Turkish Strait System (TSS) not only one of the most important channel for merchant but also significant biological channel for all kind of aquatic creatures of Black sea and Mediterranean Sea. The SoI is north part of TSS (Yüce and Gazioğlu, 2006; Terzi and Gazioğlu, 2014). Many of the varieties of fish migration hunting value are realized through the TSS where have been and continue to be one of the most important waterwards in the World. The SoI is generally a noisy channel, no comparisons between current and past OAN levels.

There is also very heavy ferry traffic for domestic transport on the SoI. In addition to merchant and domestic passenger ships, the marine traffic is busy by vessels with various aims. Additionally local maritime traffic is another important acoustic sources which are more than 3000 local traffic elements in SoI (Kesgin and Vardar, 2001).

In shallow and narrow channel such SoI the noise levels are extremely variable in time and space and are generally higher than levels recorded in the deep sea, because of the depth and the presence of different sound sources. Shallow water $(<200 \mathrm{~m})$ OAN are predictable to be louder (Wenz, 1962) and more variable than in deep water (Urick, 1983; Richardson et al., 1995; Jr and Moore, 1995; Merchant et al., 2012a;). 

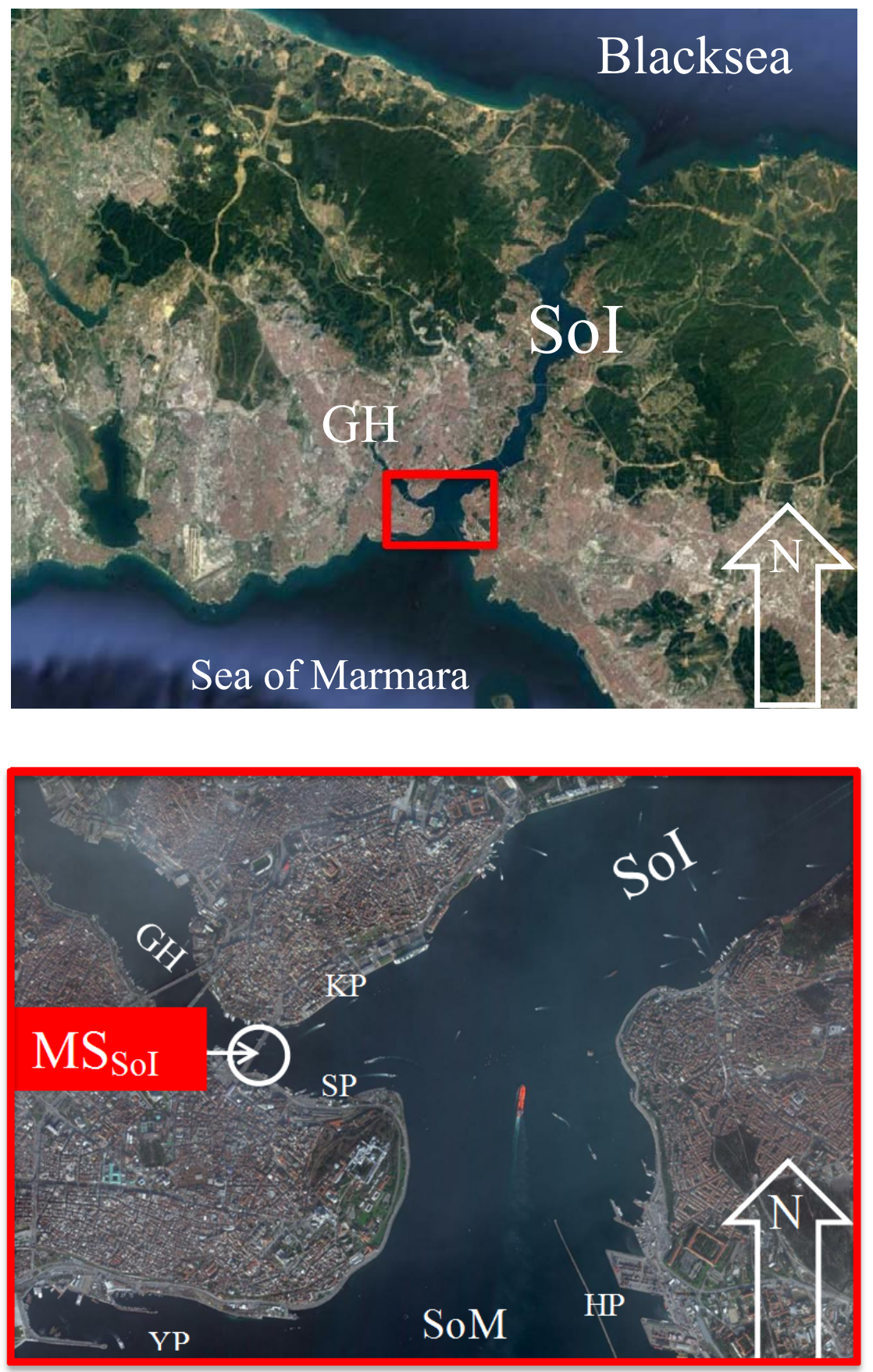

Fig. 4. Measurement Station $\left(\mathrm{MS}_{\mathrm{SoI}}\right)$; SoI: Strait of Istanbul; GH: Golden Horn; SoM: Sea of Marmara; YP: Yenikapı Port; HP: Haydarpaşa Port; SP: Sirkeci Port; KP: Karaköy Port. 
Channels and shallow water reflection, interference, scattering to be more of such events increases transmission losses of the sound waves emitted at longer distances. Therefore, these types of media, buyers reaching sound waves are emitted from the intense noise sources in the closer distance

\section{Measurement station}

Measuring station $\left(\mathrm{MS}_{\mathrm{SoI}}\right)$ with an intense and continuous traffic flow in the Golden Horn where it opens SoI was established in the northern foot of the bridge (Fig. 4). Around this point, it is the best platform to measure the effects of transiting ships, but intense local traffic in an area located approximately 750 meters radius (etc: interior city lines ferry ports in Karaköy and Eminönü; car-ferry dock in Sirkeci, local boat lines TURYOL dock is situated in east side of $\left.\mathrm{MS}_{\mathrm{SoI}}\right)$. The presence of a large number of boats that pass under the bridge, pier of intense activity and brings to the $\mathrm{MS}_{\mathrm{SoI}}$ an intersection during maneuvers of ships and boats. The $\mathrm{MS}_{\mathrm{SoI}}$ has approximately 40 meters depth.

Measurement was carried out by international patent received booster for this survey EP2975432 by Gazioğlu et al. (2016). In shallow water, the audio channels are often in regions close to the surface. Therefore, in shallow water, hydrophones deployed close to the surface to transmit voice is getting better. Records made during the current listening, due to intense maritime traffic in the region already characterized the OAN in the higher dimensions, and ship maneuvering of vessels (astern, uncomfortable, slow down, bow trust is run etc.), noticeable changes were observed. Ambient noise of SoI could be saved as data using by non-directional hydrophone.

According to Urich (1983) ve Hodges (2010) OAN could descripe as; except for the sound of their instruments and equipment used for measurement is defined as continuous and discontinuous noise from all sources in the AEE. Analysis of components of different frequencies that make up the OAN is possible with frequency analysis. In this study, the frequency analysis carried out, the distribution of the frequency of the noise levels are examined using bu "Sigview" program to generate $1 / 3$ octave graphics which shows relationship between sound level $(d B$ re $1 \mu P a)$ and the frequency bands $(\mathrm{Hz}) .1 / 3$ octave band analysis method was used in sample station which is situated in month of Golden Horn and south part of SoI. Graphics are produced according to this method. These graphs overall sound level $(\mathrm{dB}$ re $1 \mu \mathrm{Pa})$, frequency bands $(\mathrm{Hz})$ shows the variation. Octave bands; frequency axis (values) in certain parts of width (tapes) are separating system. The lower limit for each band has a center frequency and the upper limit values.1/3 octave band in the band limits approximately, is calculated as follows:

$$
\begin{aligned}
& \mathrm{F}_{\text {lwr }}=10^{\left(-\frac{1}{20}\right)} \times \mathrm{F}_{\mathrm{C}} \\
& \mathrm{F}_{\text {top }}=10^{\left(\frac{1}{20}\right)} \times \mathrm{F}_{\mathrm{C}}
\end{aligned}
$$

"Flwr" lower frequency value, "Ftop" high frequency and "FC" represents the center frequency. 1/3 octaves of bandwidth, fixed as a percentage increase of approximately $23.2 \%$ (Erbe, 2011).

The average volumes of the entire record made in the estuary about are focused $20-900 \mathrm{~Hz}$ frequencies $(3-18$ bants) of sample station. Maximum number of peaks observes in 40-200 $\mathrm{Hz}$. Our work is fully compatible with Wenz (1962) sea traffic curves which are given in Fig. 1a. In this case, the OAN is dominated by maritime traffic in $\mathrm{MS}_{\mathrm{SoI}}$.

All record 1/3 octave band analysis; The average maximum sound level measurements we did in the $\mathrm{MS}_{\text {SoI }} 10$ points in bands $(125 \mathrm{~Hz})$ serves approximately $116 \mathrm{~dB}$ re $1 \mu$ p to. This value is changing over time during the volume measurement shows the average of the current frequency. If the measurement is that all measurement or thinning out the traffic during certain parts of the section instead be analyzed; In SoI local marine traffic is causing noise in the 2 and $10 \mathrm{kHz}$ range. The assessment of marine traffic noise in SoI is complicated by the presence of both intermittent noises from SoI and OAN from distant shipping. Noise of 
sailing ship from north to south is $10 \pm 3 \%$ less than sailing ship from south to north part of SoI is observed in $\mathrm{MS}_{\mathrm{SoI}}$. Strait of Istanbul represent one of the greatest challenges to the management of anthropogenic noise due to anthropogenic use, the presence of complex sound fields, and the variety of sources, including from a range of vessel types and numbers. Certain parts of the section instead be analyzed; Maritime traffic in the $\mathrm{MS}_{\mathrm{Sol}}$, the impact on underwater OAN will be determined more clearly.

\section{Results}

Underwater Noise Pollution is also being linked with behavioral changes that have been seen in marine creatures around the world, which is a particularly flexible phenomenon both in space and time in aquatic environments. In recent decades UNP from anthropogenic activities has increased dramatically. This increase is set to carry on and poses a potentially major threat to marine creatures of many kinds worldwide. It is extremely important that we make sure that all the sounds we produce are at a low enough OAN level that we are sure that there are no anxiety, disruptions and displacement to marine creatures.

\begin{tabular}{|c|c|c|c|c|c|c|c|}
\hline $\begin{array}{c}\text { Ban } \\
\mathbf{t}\end{array}$ & $\mathrm{F}_{\mathrm{lwr}}(\mathrm{Hz})$ & $\mathrm{F}_{\mathrm{C}}(\mathrm{Hz})$ & $\mathrm{F}_{\text {top }}(\mathrm{Hz})$ & Bant & $\mathrm{F}_{1 \mathrm{wr}}(\mathrm{Hz})$ & $\mathrm{F}_{\mathrm{C}}(\mathrm{Hz})$ & $\mathrm{F}_{\text {top }}(\mathrm{Hz})$ \\
\hline 1 & 14,1 & 16 & 17,8 & 16 & 447 & 500 & 562 \\
\hline 2 & 17,8 & 20 & 22,4 & 17 & 562 & 630 & 708 \\
\hline 3 & 22,4 & 25 & 28,2 & 18 & 708 & 800 & 891 \\
\hline 4 & 28,2 & 31,5 & 35,5 & 19 & 891 & 1000 & 1122 \\
\hline 5 & 35,5 & 40 & 44,7 & 20 & 1122 & 1250 & 1413 \\
\hline 6 & 44,7 & 50 & 56,2 & 21 & 1413 & 1600 & 1778 \\
\hline 7 & 56,2 & 63 & 70,8 & 22 & 1778 & 2000 & 2239 \\
\hline 8 & 70,8 & 80 & 89,1 & 23 & 2239 & 2500 & 2818 \\
\hline 9 & 89,1 & 100 & 112 & 24 & 2818 & 3150 & 3548 \\
\hline 10 & 112 & 125 & 141 & 25 & 3548 & 4000 & 4467 \\
\hline 11 & 141 & 160 & 178 & 26 & 4467 & 5000 & 5623 \\
\hline 12 & 178 & 200 & 224 & 27 & 5623 & 6300 & 7079 \\
\hline 13 & 224 & 250 & 282 & 28 & 7079 & 8000 & 8913 \\
\hline 14 & 282 & 315 & 355 & 29 & 8913 & 10000 & 11220 \\
\hline 15 & 355 & 400 & 447 & 30 & 11220 & 12500 & 14130 \\
\hline
\end{tabular}

The pilot results showed that features of OAN in SoI is very high due to natural channel structure and shallow waters. South part of SoI is much nosier than north part of it due to local marine traffic. Additionally small boats which are technical equipment as lower quality are used for local marine traffic as it is well known that noise created by different types of boats diverse and depended on several features such as engine (capacity, size, type, etc.), shape, speed and size of them. Ships are armed with current technology, use controllable pitch propellers to handle speed changes in conjunction with medium speed diesels which are some $20 \mathrm{~dB}$ noisier for the same horsepower than traditional ones. Additionally more powerful generators of various sizes and much more electric and liquid fuel engines equipped 
with ships which are nosier than ever. They put out line spectra with a $7 \mathrm{~Hz}$ fundamental across the entire low frequency band, since their average $\mathrm{rpm}$ is $450 \pm 100$. The present trend toward using medium-speed diesels shown in this figure may have a very significant impact on noise in the future.

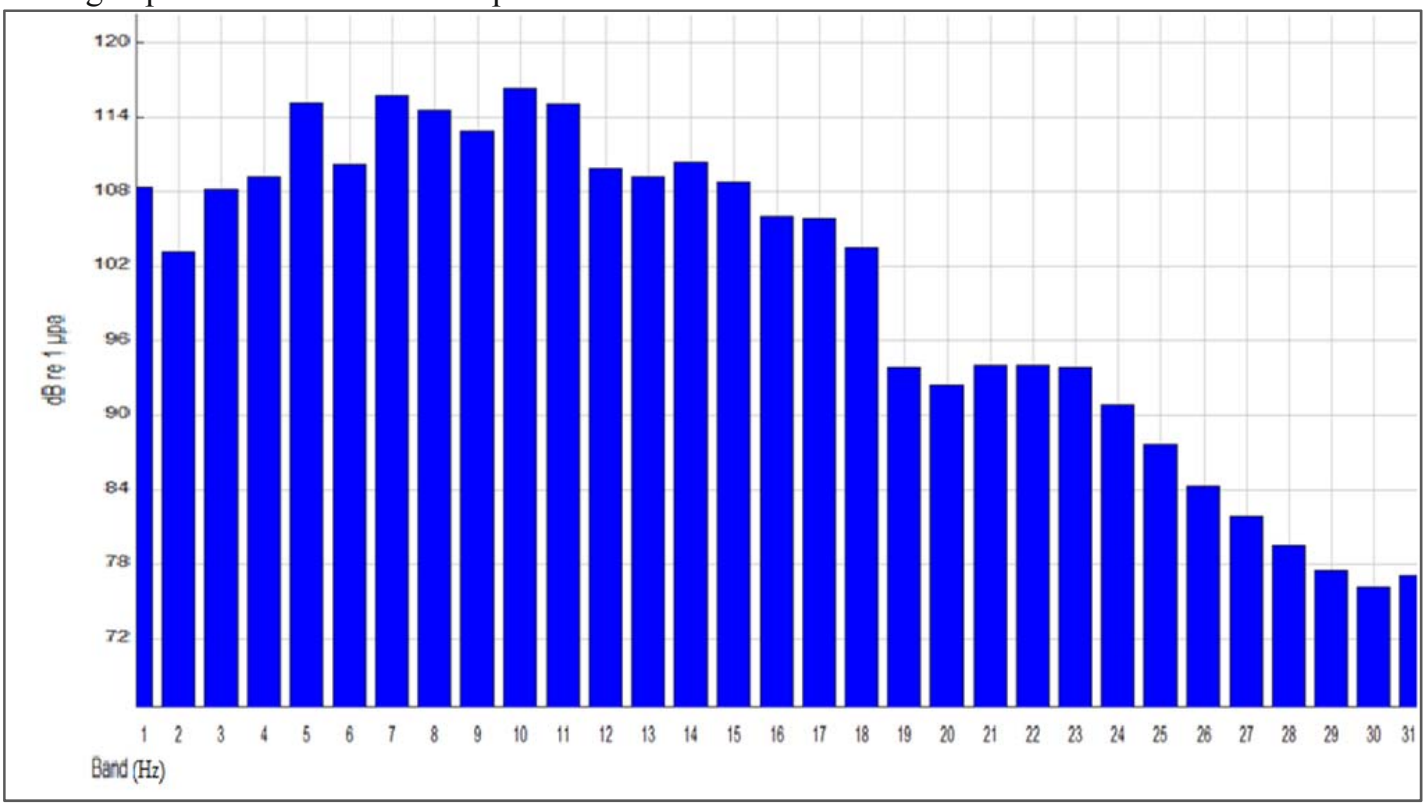

Fig. 5. 1/3 octave band frequency analysis histogram of $\mathrm{MS}_{\mathrm{SoI}}$

The marine traffic noise recorded in the $\mathrm{MS}_{\mathrm{SoI}}$ is shown in Figure 6. Sound intensity in octave band analysis of the highest, average and lowest sections due to marine traffic in the register of the $\mathrm{MS}_{\mathrm{SoI}}$. The whole record was selected and analyzed in amplitude-time graphs, in units of
30 seconds through the "Sigview" program. Three 30-second segments for average loudness and two 30-second segments for lowest loudness. When this choice is made, the parts of the sea traffic effect that are most intense in the noisy environment are preferred.

Table 3. Ship mean broadband sound pressure levels $(20-40,000 \mathrm{~Hz})$ in sample station.

\begin{tabular}{|l|l|}
\hline & dB \\
\hline All Classes combined in SoI & $110 \pm 4$ \\
\hline Bulk Carrier & $112 \pm 5$ \\
\hline Container & $116 \pm 5$ \\
\hline Tug & $108 \pm 3$ \\
\hline Cargo & $113 \pm 3$ \\
\hline Tanker & $111 \pm 2$ \\
\hline Fishing & $121 \pm 2$ \\
\hline Local Boats & $97 \pm 1$ \\
\hline
\end{tabular}


The chart of the ship-generated sea traffic noise was produced as a characteristic curve in general in $\mathrm{MS}_{\mathrm{SoI}}$ (Fig. 6). Each of the curves has a wide hill in the region of $20-900 \mathrm{~Hz}$ (3.18 bands). These peak shape and frequency domains are similar to Wentz (1962) marine traffic curves (Figure 1a, 3). The peaks on the curves in the graph, each curve is different because of sound characteristics of the selected recording parts for the highest, average and lowest sound intensity. In the peak loudness curve, the peaks are more pronounced and sharp than the other curves. This is due to the fact that a boat with extreme acoustical properties suppresses other audio sources in the environment at certain frequencies, and the recorded underwater environment is dominated by the noise at that frequency. The propeller that emanates from a boat with extreme acoustics, and the frequencies at which machine sounds dominate, appear to be distinctive peaks. The peak at the highest and the mean loudness curves and at the 10th lane in the entire recording is not significant in the lowest loudness curve. Due to the marine traffic which is very close to the measuring point and dominates the whole records with a track record in the low volume it is due to the relatively far away. Band 10 (112 - $141 \mathrm{~Hz})$ Fig. 5 and Table 2 is a frequency zone that contains both propeller and machine effects. As mentioned before; the more reflection, interference, scattering phenomena such as channel and shallow water increase the transmission losses of sound waves spreading over long distances. Ship mean broadband sound pressure levels $(20-40,000 \mathrm{~Hz})$ in sample station given in Table 3 . On the $1 / 3$ octave band analysis chart of the whole record (Figure 5), the distinct peak in the 5th band is not found in the graphics of the recording tracks dominated by the sea traffic noise (Fig. 6). This shows the presence of an audio source with a different character, which affects the entire recording, apart from the marine traffic.

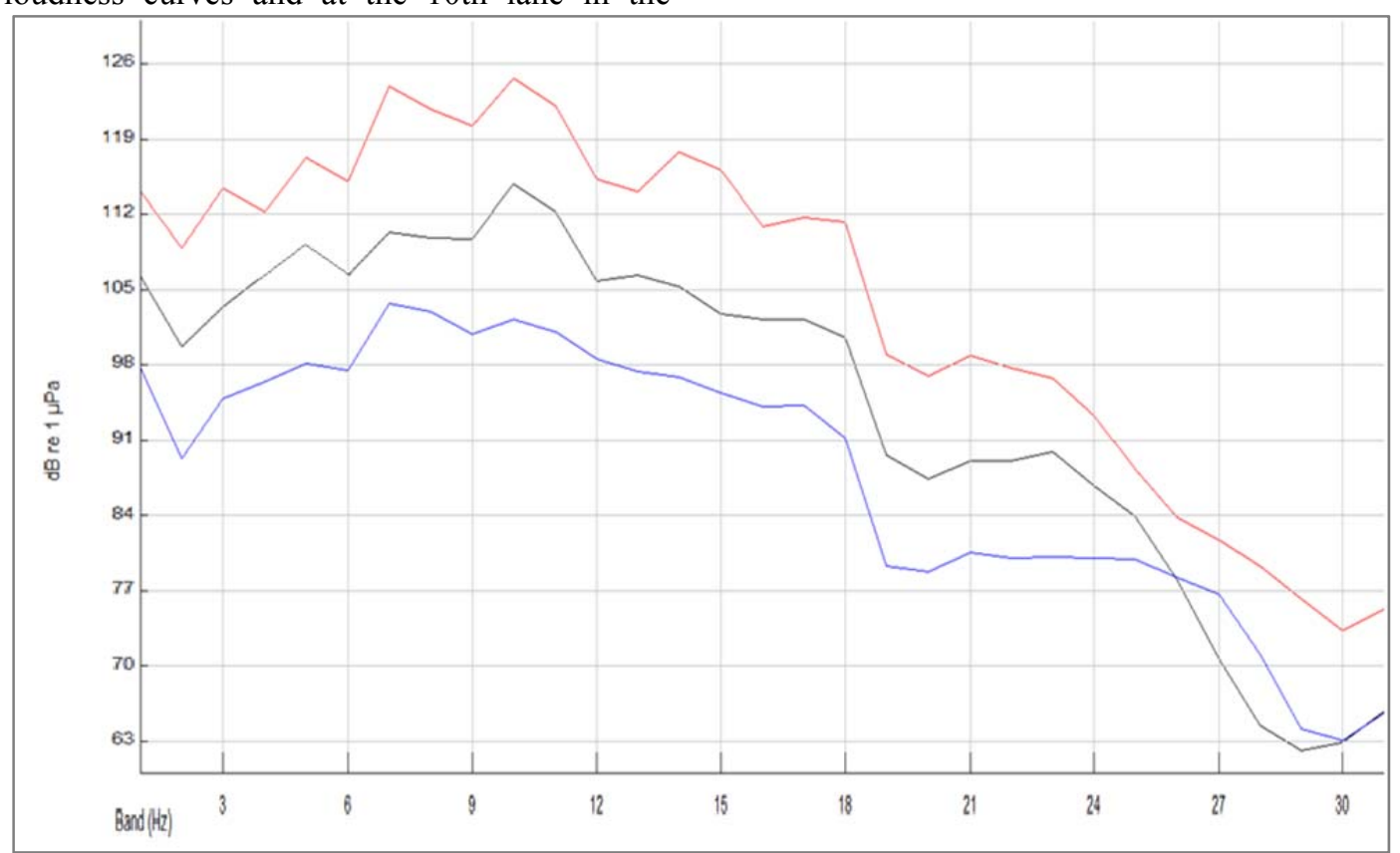

Figure. 6. Compare 1/3 octave band analysis of 30 second parts of highest (Red Line), average (Black Line) and lowest sound (Blue Line) intensities in $\mathrm{MS}_{\mathrm{SoI}}$

It is known that sound waves radiating in an environment move towards regions where sound velocity is low. Differences in depth, temperature, pressure and salinity cause stratification in the seas. This situation changes the propagation speed of the voice in the ME. 
The movement of sound waves in the underwater environment, where the sound velocity is low, causes the sound channels to form at various depths and thicknesses. The band is acting like a pipe that focuses on the sound energy. The most prominent oceanographic feature of the SoI is a stratified structure. For this reason, there are interventions between the $\mathrm{OAN}_{\text {top }}$ measured along the top layer and the $\mathrm{OAN}_{\text {mix }}$ measured in the mixture layer and the bottom layer. In order to investigate the properties of these initiatives, it is necessary to develop hydrophones suitable for the layered system.

Organizations have begun to address the problem of sound propagation due to UNP, urging that governments work together. According to United Nations (UN) Convention on the Law of the Sea forbids all kind of pollution that can damage marine wildlife. The recent years it has seen a remarkable increase in awareness of OAN as an issue that must be addressed multilaterally. The understanding of UNP and its impacts needs to be investigated by the international scientific institutions (IPCC, IOC, IMO, etc.) which must be supported long-term records and measurements in diverse marine environments. UNP affects marine organisms are fully understood, with only some aspects and an extremely small proportion of the marine organisms having been investigated. A delegation of representatives from several of the organizations working on the UNP issue attended the 5th Informal Consultative Process on the UN Convention on Oceans and the Law of the Sea to increase awareness among governments about the need to address UNP which has to be developing international standards regulating UNP in the world's oceans. This will help to document the past changes in OAN besides to provide a baseline for future changes. The EU's Marine Strategy Framework Directive requires member states to attain Good Environmental Status in their seas by 2020, the one of the most important challenge to determine UNP will be pollutant.

The UNP is getting steadily increasing and growing worse for another reason. As we're making more noise, we're also making the ocean better at transmitting it. Carbon dioxide, which is directly anthropogenic activities by the global ocean, induces major changes in oceans chemistry that could have dramatic impacts on both biological ecosystems in the ocean surface and it will be the cause of the increased OAN. Specifically $\mathrm{CO} 2$ spewed into the atmosphere by burning of the fossil-fuel dissolves into the sea causes more acidic condition in oceans which as a strong connection between chemical oceanography and sound propagation.

Underwater could define acoustic emissions as a new category of pollutant. Additionally Underwater Noise Pollution could be added in conception of ship oriented pollution. Some environmental ethic limitation might be proposed on VTS, ADCP, etc. equipment by IALA for ship detection and on sonars by IHO/IMO for marine surveys.

\section{Acknowledgments}

This work was supported by the Research Fund of the Istanbul University (Project number 454).

\section{References}

Aguilar Soto, N., Johnson, M., Madsen, P.T., Tyack, P.L., Bocconcelli, A. and Fabrizio B.J. (2006). Does intense ship noise disrupt foraging in deep-diving cuvier's beaked whales (Ziphius Cavirostris)? Mar. Mammal Sci. 22, 690-699.

Andrew, R.K., Howe, B.M., Mercer, J.A., and Dzieciuch, M.A. (2002): Ocean ambient sound: comparing the 1960s with the 1990s for a receiver off the California coast, Acoust. Res. Lett. Online, 3: 65- 70.

Arveson, P. and Vendittis, D. (2000). Radiated noise characteristics of a modern Cargo ship. J. Acoust. Soc. Am. 107, 118-129.

Bass A.H. and McKibben J.R. 2003. Neural mechanisms and behaviors for acoustic communication in teleost fish. Prog Neurobiol 69:1-26.

Bittencourt. L.,Carvalho. , R.R. Lailson-Brito, J. and Azevedo. A.F. (2014). Underwater noise pollution in a coastal tropical environment. Marine Pollution Bulletin, Vol. 83, Issue. 1, 331-336. 
Bowen B.W., Meylan A.B. and Avise J.C. (1989). An odyssey of the green sea turtle: Ascension Island revisited. Proc Natl Acad Sci USA 86:573-576

Castellote, M., Clark, C.W. and Lammers, M.O. (2012). Acoustic and behavioural changes by fin whales (Balaenoptera physalus) in response to shipping and airgun noise. Biol. Conserv. 147, 115-122.

Dekeling, R.P.A., Tasker, M.L., Ainslie, M.A., Andersson, M., André, M., Castellote, M., Borsani, J.F., Dalen, J., Folegot, T., Leaper, R., Liebschner, A., Pajala, J., Robinson, S.P., Sigray, P., Sutton, G.,. Thomsen, F., Van der Graaf, A.J.,. Werner, s., Wittekind, D. and J.V. Young. (2013). Monitoring guidance for underwater noise in European seas-2nd Report of the Technical Subgroup on Underwater noise (TSG Noise). Part II Monitoring Guidance Specifications Interim Guidance Report: $26 \mathrm{p}$.

Erbe, C. (2011). Underwater Acoustics: Noise and the Effects on Marine Mammals JASCO Applied Sciences.

Etter, P.C. (2012). Advanced Applications for Underwater Acoustic Modeling, Advances in Acoustics and Vibration Vol. 2012: 28p.

Garrett, J.K., Blondel, P.H., Godley, B.J., Pikesley, S.K., Witt, M.J. and Johanning, L. (2016). Long-term underwater sound measurements in the shipping noise indicator bands $63 \mathrm{~Hz}$ and $125 \mathrm{~Hz}$ from the port of Falmouth Bay, UK, Marine Pollution Bulletin, Volume 110(1): 438448.

Gazioğlu, C., Müftüoğlu, A.E. and Okutan, V. (2016). Low Coast Hydrophone European Patent Office: EP2975432.

Gazioğlu, C., Müftüoğlu, A.E., Demir, V., Aksu, A. and Okutan, V. (2015). Connection between Ocean Acidification and Sound Propagation. International Journal of Environment and Geoinformatics Vol. 2(2): 16-26.

Halpern, B. S., Walbridge, S., Selkoe, K. A., Kappel, C. V., Micheli, F., D'Agrosa, C., Bruno, J. F., Casey, K. S., Ebert, C., Fox, H. E., Fujita, R., Heinemann, D., Lenihan, H. S., Madin, E. M. P., Perry, M. T., Selig, E. R., Spalding, M. and Steneck, R. (2008). A
Global map of human impact on marine ecosystems. Science 319: 948-952.

Hamilton P.V. and Russell B.J. (1982). Field experiments on the sense organs and directional cues involved in offshoreoriented swimming by Aplysia brasiliana Rang (Mollusca: Gastropoda). J Exp Mar Biol Ecol 56:123-143.

Herrnkind W and Kanciruk P. (1978). Mass migration of spiny lobster, Panulirus argus (Crustacea: Palinuridae): synopsis and orientation. In: Schmidt-Koenig K, Keeton WT (eds) Animal migration, navigation, and homing. Springer-Verlag, New York, 430-439.

Hildebrand J.A. (2009). Anthropogenic and natural sources of ambient noise in the ocean. Marine Ecology Progress Series 395:5-20.

Hobson K.A. (1998). Natal origins of migratory monarch butterflies at wintering colonies in Mexico: new isotopic evidence. Proc Natl Acad Sci USA 95:15436-15439

Hodges, R.P. (2010): Underwater Acoustics Analysis, Desing and Performance of Sonar. John Wiley and Sons, Ltd., Publication.

Jr, C.G. and Moore, S. 1995. Man-made noise. Marine Mammals and Noise: 101-158.

Kastelein, R.A.; Heul, S.; Verboom, W.C.; Jennings, N.; Veen, J.; de Haan, D. (2008). Startle response of captive North Sea fish species to underwater tones between 0.1 and 64 kHz. Mar. Environ. Res., 65: 369-377.

Kesgin, U. and Vardar, N. (2001). A study on exhaust gas emissions from ships in Turkish Straits, Atmospheric Environment 35: 18631870.

Ketten, D. R. and Wartzok, D. (1999). 3Dimensional Reconstructions of the Dolphin Ear. Sensory Abilities of Cetaceans: Laboratory and Field Evidence. edited by J. A. Thomas and R. A. Kastelein. Vol. 196.

McDonald, M.A., Hildebrand, J.A. and Wiggins, S.M. (2006). Increases in deep ocean ambient noise in the Northeast Pacific west of San Nicolas Island. California. J. Acoust. Soc. Am. 120: 711-718.

McKeown B.A. (1984). Fish migration. Croom Helm, London.

Merchant, N. D., Matthew, J.W., Blondel, P., Godley, B.J and Smith, G.H. (2012). 
Assessing sound exposure from shipping in coastal waters using a single hydrophone and Automatic Identification System (AIS) data, Marine Pollution Bulletin, Vol.64: 1320-1329.

Merchant, N.D., Blondel, P., Dakin, D.T. and Dorocicz, J. (2012b). Averaging underwater noise levels for environmental assessment of shipping, J. Acoust. Soc. Am., 132: EL343-EL349.

Mutlu, E. (2005). A comparison of the contribution of zooplankton and Nekton Taxa to the near-surface acoustic structure of three Turkish Seas, Marine Ecology-An Evolutionary Perspective 26: 17-32.

Popper A.N. and Carlson T.J. (1998). Application of sound and other stimuli to control fish behavior. Trans Am Fish Soc 127: 673-707.

Rako, N., Fortuna, C.M., Holcer, D., Mackelworth, P., Nimak-Wood, M., Pleslić, G., Sebastianutto, L., Vilibić, I., Wiemann, A. and M. Picciulin, M. (2013). Leisure boating noise as a trigger for the displacement of the bottlenose dolphins of the Cres-Lošinj archipelago (northern Adriatic Sea, Croatia), Mar. Pollut. Bull., 68: 77-84.

Richardson, W.J. Greene Jr., C.R. Malme, C.I. and Thomson, D.H. (1995). Marine mammals and noise Academic Press, 576p.

Richardson, W.J., Greene Jr., C.R., Malme, C.I. and Thomson, D.H. (1995). Marine Mammals and Noise, 1st ed. Academic Press, San Diego. 576p.

Ross, D. (1976). Mechanics of Underwater Noise, Pergamon Press, New York: 375p.

Ross, D. 2005. Ship sources of ambient noise, IEEE Journal of Oceanic Engineering, Vol. 30(2): 257-261.

Sebastianutto, L., Stocker, M. and Picciulin, M. (2016). Communicating the Issue of Underwater Noise Pollution: The Deaf as a Fish Project. Effects Of Noise On Aquatic Life II, Advances in Experimental Medicine and Biology, Vol. 875, 993-999.

Simpson SD, Meekan M, Montgomery J, McCauley R. and Jeffs A. (2005). Homeward sound. Science 308:221.

Slabbekoorn, H., Bouton, N., Opzeeland, I., Coers, A., Cate, C., and Popper, A. N. (2010). A noisy spring: the impact of globally rising underwater sound levels on fish. Trends in ecology and evolution, vol. 25 (7): 419.

Swartz S.L., Jones M.L., Goodyear J., Withrow D.E. and Miller R.V. (1987). Radiotelemetric studies of gray whale migration along the California coast: a preliminary comparison of day and night migration rates. Rep Int Whal Commn 37: 295-299.

Tasker, M., Amundin, M.,Andre, M., Hawkins, A., Lang, W., Merck, T., Scholik-Schlomer, A., Teilmann, J., Thomsen, F. and Werner, S. (2010). Marine Strategy Framework Directive Task Group 11 Report: underwater noise and other forms of energy JRC Scientific and Technical Reports (2010), 55p.

Terzi H and Gazioğlu C. (2014). "Finding Solutions Before Accidents Happen", XVIII. IALA AISM 2014, A Coruna, ISPANYA, 27-31 May 2014, 1-10.

Terzi H and Gazioğlu C. (2016). "New Era In Maritime Safety: Safety Culture ", 13th International IALA VTS Symposium International framework for VTS and national regulatory provisions, Kuala Lumpur, MALEZYA, 8-12 Ag 2016, 1-10.

Tolimieri, N., Jeffs, A. and Montgomery, J.C. (2000). Ambient sound as a cue for navigation by the pelagic larvae of reef fishes. Mar Ecol Prog Ser. Vol.207: 219224.

Tombul, S. and Alpar, B. (2016). Acoustical Properties and Ambient Noise Measurements In The Sea Of Marmara, The Sea Of Marmara Marine Biodiversity, Fisheries, Conservation and Governance (Eds: Özsoy,E., Çağatay, M.N., Balkıs, N., Balkıs, N and Öztürk, B.): 198-208. ISSN: 978-975-8825-34-9.

Tyack, P.L. (2008). Implications for marine mammals of large-scale changes in the marine acoustic environment. J. Mammal. Vol 89: 549-558.

Ülüğ, U. (2009). Analysis and Modeling of Underwater Ambient Noise of İstanbul Strait, Thesis, İstanbul Technical University (In Turkish).

Urick, R. (1983). Principles of underwater sound: $423 \mathrm{p}$.

Van der Graaf, A., Ainslie, M., André, M., Brensing, K., Dalen, J., Dekeling, R., 
Robinson, S., Tasker, M., Thomsen, F. and Werner, S. (2012). European Marine Strategy Framework Directive-Good Environmental Status (MSFD GES): report of the Technical Subgroup on Underwater noise and other forms of energy: $75 \mathrm{p}$.

Van der Schaar, M., Ainslie, M.A., Robinson, S.P., Prior, M.K. and André, M. (2014). Changes in $63 \mathrm{~Hz}$ third-octave band sound levels over 42 months recorded at four deep-ocean observatories, J. Mar. Syst., 130: 4-11.

Veirs, S., Veirs, V. and Wood, J.D. (2016). Ship noise extends to frequencies used for echolocation by endangered killer whales. PeerJ 4:1657.

Wales S.C. and Heitmeyer RM. (2002). An ensemble source spectra model for merchant ship-radiated noise. The Journal of the Acoustical Society of America 111(3):1211_1231.

Wenz, G.M. (1962). Acoustic ambient noise in the ocean: spectra and sources. The Journal of the Acoustical Society of America, 34(12): 1936-1956.

Yüce H. and Gazioğlu C. (2006). "Maritime Security Challenges Ahead in the Black Sea", Journal of Black Sea/Mediterranean Environment, Vol.12 (3): 233-250. 